\title{
Statistical Analysis and Forecast of Assessing the Development of Grain Market on the South of Russia
}

\begin{abstract}
Submitted 19/01/19, 1st revision 23/02/19, 2nd revision 18/04/19, accepted 28/05/19
Smertina E.N. ${ }^{1}$, Demyanenko E.Yu., ${ }^{2}$ Blokhina V.G., ${ }^{3}$ Radchenko Yu.V. ${ }^{4}$

Abstract:

Purpose: The article aims to identify the trends in the development of grain production in the Rostov region. The expert assessment of the production and export of grain, with a breakdown of the main achievements, is very important from the point of view of forecasting the development of the results of agricultural production of farmers in this region.

Design/Methodology/Approach: To identify the prospects for the development of production for grain crops in the Rostov region, it is necessary: first, to identify the main directions of their development, second, to identify negative phenomena in this sector and third to identify the main activities that will help to eliminate agricultural sector reform.

Findings: To identify trends in the development of grain production in the Rostov region, as well as assess the export volume of grain abroad, detailing the main achievements and results of agricultural production of farmers, a large array of statistical data from leading Russian and international analytical agencies were used. By expert evaluation, they were processed, which allowed the authors to make a forecast of grain production and export.

Practical Implications: The results of the study can be used to draw up sound plans for the volumes of grain production and grain exports, as well as to further assess the forecasts for the development of agricultural production.

Originality/Value: The study made it possible to draw a conclusion on the development of agricultural production in part of the grain market in a single region.
\end{abstract}

Keywords: Agricultural exhibition, analytical agencies, grain market, competitive price.

JEL Code: D12, O13, P25, P27.

Paper Type: Research article published in a special issue dedicated to Russian economy.

Section 8: Business and Economic Issues.

\footnotetext{
${ }^{1}$ Candidate of Science (Economics), Associate Professor of the Department of "Accounting”, Rostov State University of Economics, Rostov-on-Don, elesmertina@mail.ru

${ }^{2}$ Candidate of Science (Economics), Associate Professor of the Department of "Accounting", Rostov State University of Economics, Rostov-on-Don, demellina21@yandex.ru ${ }^{3}$ Candidate of Science (Economics), Associate Professor of the Department of "Business Analysis and Forecasting”, Rostov State University of Economics, bvg0508@yandex.ru ${ }^{4}$ Candidate of Science (Economics), Associate Professor of the Department of "Business Analysis and Forecasting”, Rostov State University of Economics, rijka@yandex.ru
} 


\section{Introduction}

In October 2017 the Ministry of Agriculture of the Russian Federation organized the XIX Russian agricultural exhibition "Golden Autumn" at the Exhibition Centre of Economic Achievements (VDNH) in Moscow. It was the first time when Rostov region presented its products and investment opportunities on four sites. The main stand covering 150 square meters was devoted to the 80th anniversary of Rostov region and the record harvest in 2017. Within the program of the all-Russian agricultural forum governor Vasiliy Golubev signed 2 investment projects in the total amount of 5,2 billion rubles. The four exhibition days resulted in more than 100 awards of different value received by the representatives of Rostov region. "This year Rostov region has received the Grand Prix and a great number of awards", informed the first deputy of Rostov region governor Victor Goncharov. "In addition, the most awards are of the highest value: the Don participants have 46 golden medals, 35 silver and 15 bronze ones, four certificates and 3 letters of appreciations. I want to thank all the participants. Thus, the received awards prove the high quality of products made on Don".

According to the Minister of agriculture and food of Rostov region Konstantin Rachalovskiy the representatives of all agricultural industries, science and processing industries received medals and certificates. The most awards were obtained by the manufactures who won 17 gold, 12 silver and 15 bronze medals. The Don farmers took the 2 nd place on the number of awards. They have 14 medals, where five medals are gold and bronze, and there are also 4 silver ones. The eight medals, a half of which are gold ones, were given to the agricultural businesses for their achievements in growing plant products and raising soil fertility. Furthermore, the Don stockbreeders were highly appreciated. Breeding stock-rearing farms of Rostov region got 6 highest awards for developing stock and poultry breeding.

The representatives of the Don agricultural science were awarded by 5 medals ( 2 gold, 2 silver and 1 bronze medals) for creating new kinds and hybrids of crops. In addition, Rostov region was given 5 medals, where are 2 gold and 3 silver ones, for introducing innovations in the agriculture. Eight fishing entities of Rostov region participated in the exhibition. Fishery 'Socialisticheskiy put' ltd gained the gold medal for its products. The Don vets got the silver medal for the development, production and introduction of efficient veterinary drugs.

\section{2. 'Rostov Phenomenon' of Grain Production}

The unprecedented grain harvest has been collected in Rostov region for the third consecutive year. The Don farmers collected more than 12,3 million tons of early grain crops. This is the best outcome in the country and the highest one for the eighty-year history of Rostov region. "The cultivated fields have never witnessed such results. These golden grains contain the dedicated work of my countrymen. I am proud of you 
and your active love to your native land, dear friends", wrote the head of the region Vasiliy Golubev on his Twitter page (Kommersant, 2017).

The fourth year Rostov region increase in grain production breaks its own records. Some experts call it "Rostov phenomenon". Farmers and the head of the region believe the reasons for such success are the combination of some factors: acceptable weather conditions, growing volume of state support, constant improvement of technologies and dedicated work of villagers. At the beginning of the year the specialist doubted that they could break the record. The cold and rainy spring led to postponing the time of spring field works. Consequently, harvesting began later compared to the previous years. Nevertheless, the farmer managed to improve the situation during it.

The highest productivity in Myasnikovskiy area is more than 58 quintals of the grain from a hectare. "The secret of success is in applying the advanced kinds of grains and technologies. Our farms use only the best kinds including Don selections adjusted to our natural climate conditions", says the deputy of the area on agriculture Nerses TerAkopyan. "We are trying to upgrade our technology park to increase the productivity and reduce the cost. Great funds are given to buy equipment including from the region budget. It would be a crime not to use it".

According to the governor Don region has not exhausted its potential yet. However, the focus is to be brought on processing the raw material within the region. It provides new workplaces in high-technology spheres of production, ensures its diversification, offers the added value, increase investment and tax flows into the local region. In the nearest future there will appear a complex on deep grain processing and production of amino acids with the capacity of 250 thousand tons of raw materials per day in Volgodonsk. Moreover, it will have the potential to increase the capacity up to 500 thousand tons. The largest corn manufacturer of the South of Russia declared the plans to double the volume of processing. There are also the negotiations with investors about building a few cereal enterprises and mills along the Don. All these enterprises intend to sell their products both inside and outside the country.

Rostov region takes up more than 100 thousand square kilometers. The region is one of the biggest food and agricultural raw material exporters of the Russian Federation. There are 73 grain elevators and 20 port terminals with the total capacity of lump storage accounted for 4,7 million tons on the territory of the region.

After introducing economic sanctions against Russia there is an annual increase in the volume of agricultural production. Nowadays the agricultural producers are world leaders on gain export. In other words, if in the 80s the USSR exported 30-47 million tons of grain per year, Russia is prepared to deliver over 40 million tons to the foreign markets. However, it should be noted that port terminals, the capacity on storing and transporting grain on export routs did not appear to be ready for such grain volume. The decreasing price on the grain market does not assume active sales but the 
possibility to lose grain due to the lack of storage place encourages traders to realize their goods at unfavorable prices despite the high freight rates. According to the forecast of company "SovEcon" this year grain exports may account for record 44 million tons including wheat exports 32,4 million tons, barley exports 4,3 million tons, corn exports 5,7 million tons. On leading experts' opinion, the infrastructural constraints prevent the further growth of export.

In the statistical survey US Department of Agriculture (USDA) has increased the total forecast of grain harvest in Russia by 5,3 tons up to 125, 3 million tons including 81 million tons of wheat. USDA does not take into account the data on the Crimea and the data on pulse crops and some grain crops such as buckwheat unlike Russian statisticians (Agroinvestor, 2018).

The Russian Ministry of Agriculture uses the conservative forecast 110 million tons in net weight. This estimate remains unchangeable almost from the beginning of 20172018 agricultural year. By the end of September the country has gathered 108,2 million tons of grain from $70,9 \%$ of all the sown area initially and according to the data of the Ministry of Agriculture that is 102,8 million tons in net weight. According to Federal statistics service Russia collected record 120,7 million tons of grains in 2017. The largest Russian industrial analytical agencies improved the forecast on grain harvest long time ago. The last estimate of "SovEcon" is 133 million ton of grains including 81,1 million tons of wheat, "Prozerno" 133,3 million, and 80,3 million consequently, the Institute for agricultural market studies (IKAR) 131,5-134 million and 81-84 million tons.

IKAR's executive director Dmitriy Rylko considers the situation as complicated: in main grain-producing regions in Russia, wheat prices have already decreased below the export parity index. That is, if in the Black Sea ports 1 ton of wheat costs approximately 10000 rubles with VAT, for instance in Orenburg, this price should be about 7000 rubles on the export parity index, in fact, it is 6000 rubles or even below. Director of "Prozerno" Vladimir Petrichenko believes the state has to support the producers by any ways as soon as possible. The Ministry of Agriculture takes the decision on how to stabilize decreasing grain prices: apart from purchasing intervention, the agreement with Russian Railways on lifting its rates is discussed to promote the export from remote regions of Central district, Volga region and Siberia.

According to the Ministry of Agriculture of Russia the forecast on grain export is 40 million tons while USDA suggests 43,1 million tons. On the 6th of September, 2017 the country exported 7,8 million tons that is by $22 \%$ more than in 2016. In August the Russian Federation exported record 4,8 million tons of grain, and it may increase the deliveries in September. "In August 2017 grain export exceeded our forecast by 4,65 million tons and reached historically record level taking into account the data on the shipment in deep-water ports-4,84 million tons", said the head of analytical center "Rusagrotrans" Igor Pavenskiy to "Interfax". The previous record was in August 2014 
4,64 million tons. In August of the previous year the export of Russian grain accounted for 4,02 million tons.

Last month Russia sent 4 million tons of wheat (3,6 million tons a year earlier) to the foreign markets, nevertheless, the record on its export was not beaten (4,21 million tons in August 2014). In comparison with the previous index the export of barley increased twice to 0,63 million tons, the export of corns grew up by five times to 116,7 thousand tons (at the expense of high carryover stocks of old harvest).

Figure 1. 15 TOP grain exporters (designed by the authors and based on the data of RUSAGROTRANS , 2016)

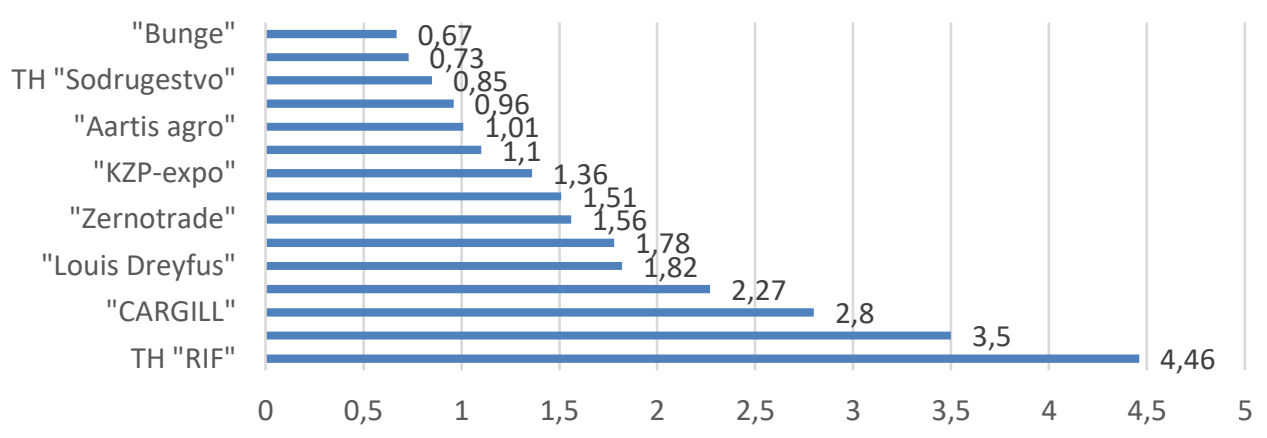

mln tons in the season of 2016/17

\section{Restructuring the Grain Producers' Market}

The practical measures of the Federal Tax Service to "whitewash" grain market resulted in the requirement to provide an essential set of supplementary documents from agricultural producers, carriers and intermediaries. In addition, the customers are to hold the primary check of these documents. Some traders on the market obtain a great number of problems. First of all, the farmers applying single agricultural tax (SAT) suffer from it due to the fact that preferential tax treatment helps them to avoid bureaucracy. "There are significant changes in the requirements to the documents on grain transportation ", says the head of the legal department of Krasnodar transport aggregator "Single center of grain carriers" Kiril Kazantzev. ,, That is why it is easier for us to work with companies who do not pay VAT. Intermediaries, VAT payers, still work in the previous mode but their operational activity has complicated manifold."

A set of documents that an agricultural producer has to collect according to the new regulations is very great. It is necessary to fill out several declarations, provide the results of laboratory analysis, a bank statement on his own tax activity, a note from Statistics department, verified cards with signature samples and seal impression in order to sell 100-200 tons of grain legally. Under such conditions, many farmers do not want to work "in white". "Contracts turned out to be complicated, the 
responsibility is greater, and it still frightens agricultural producers", notes Sidyukov. Agricultural producers experience the lack of highly qualified accountants. "They do not have the possibility to cope with paper work, maintain the VAT accounting and work in the field at the same time", explains Zlochevskiy. "The Ministry of Agriculture and Federal Tax Service should arrange some accounting outsourcing for agricultural producers applying SAT and encourage them. Otherwise, the mass transition of farmers to the General Tax Regime is unreal".

The key question is still how this restructuring of the market will influence the economy of agricultural producers applying SAT. From the point of Federal Tax Service, the agricultural producers show their interest and readiness to work with exporters and manufactures directly. Moreover, in this season they hope to receive more favorable grain prices due to the increase in prices on the foreign market as well as at the expense of direct contracts with exporters, which may raise the margin and provide the possibilities to invest in the business. The chief of practice on collaboration with companies of agricultural industry in KPMG Vitaliy Sheremet believe the state to become the only beneficiary of restructuring the market. In his opinion, traders and producers will pay for that. Furthermore, the distribution towards farmers will be higher because their margin is bigger than traders' one, and, as a result, severe competition will make them cover these expenses. Nevertheless, it would be premature to say about bankruptcy since there is still high rate of return, even under the condition of the decrease in prices.

In Zlochevskiy's opinion, if everybody worked with VAT, everybody would win producers, manufacturers, exporters. If commodity-distribution chains are built predominantly without VAT, it will solve only exporters' problems whose risks connected with possible tax refund will disappear. Applying this scheme, the manufactures are forced to take into account VAT without receiving any compensation whereas the producers will just lose money giving their products $10 \%$ cheaper than VAT payers.

In the opinion of the plant product sales director of agro holding "Kuban" Vladimir Zagrebelniy, large holdings and entities, to which exporters always pay a great attention, have not experienced any changes. Only small entities and farmers whose production volume is less than 200 tons of grains have suffered. Due to the insignificant volume and inability to coordinate their actions, farmers did not attract the exporters who are unable to encompass all small entities. "Small entities have the only outcome in this situation - to join together in the associations or be taken over by a larger enterprise", says the manager. According to the data of the National union of grain producers, about $10 \%$ of agricultural enterprises leave the market annually. Due to the low profitability in grain production, the reduction of state support per hectare, a great debt load of agricultural enterprises (more than 2 trillion rubles on the beginning of 2017), the negative changes caused by new regulations are inevitable in the industry. 
Furthermore, new requirements have created problems for exporters. All of them have to provide the information on weekly cash flow to Federal Tax Service and weekly revised register of suppliers where they write down tax reference number of contractors, consignors, details of the contract, specifications to the contract, delivery volume on specification and delivery volume de facto, product titles, the date of delivery on specification. According to Alexandr Grigoriantz, the period of concluding the contract has fallen down a few times. "Our company collects all the documents for the deal or do not sign the contract. Sometimes we may deal with one contract for a week, that took only a half an hour earlier", he said. „And such deals are more than a half. The good is often sold out by that time, as the supplier changes his mind".

Intermediary companies delivering grains bought on farms into the ports have suffered most of all from such innovations, especially, if they provided farmers with loans, fuel, seeds, and mineral fertilizers before introducing these new regulations. "Such intermediaries did a lot of useful things for farmers and facilitated the purchase to exporters, and now they are unable to work since new regulations of Federal Tax Service prohibit the signatories of the Charter to purchase the goods from traders paying VAT if it is earlier bought from the producer using the simplified taxation system", says Grigoryantz. Since the vast majority of grain producers dealing with export uses SAT, the intermediaries are unable to sell it to the exporter with VAT, even if they pay a tax. According to the Charter exporters will not buy it.

\section{Conclusion}

Holding the statistical analysis the authors have revealed that the main countriesimporters of Russian grain were Egypt (almost 1 million tons) and Turkey $(0,47$ thousand tons) in August. Tanzania entered the first five largest importers (265 thousand tons). Saudi Arabia and Iran imported on 262 thousand tons of Russian grain. The high export was ensured by the record monthly shipment of deep-water ports 2,3 million tons - with September sales at the price of \$195-196 per ton (FOB, wheat containing $12,5 \%$ of protein), high carryover stocks and high grain supply at competitive price on the behalf of Russia. According to I. Pavenskiy, currently the volume of applications for deep-water ports accounts for about 2,5 million tons, and there is an opportunity to repeat the August record of export, or Russian grain deliveries will even exceed the indexes of the previous month.

According to the data of analytical center "Rusagrotrans", Russian grain export accounted for 7,54 million tons in July-August that is by 1 million tons more (15\%) than the indexes of the previous year (6,56 million tons) due to the sufficient increase in barley and corn deliveries. Wheat exports over 2 months are 5,67 million tons $(5,63$ million tons in the previous year), barley $-1,35$ million tons (the growth by 1,9 times), corn - 0,47 million tons (the growth by 11 times). Over 2 weeks of September 2017 export wheat price with $12,5 \%$ of protein grew up by $\$ 6$ to $\$ 186$ per a ton (FOB). 
On the current analytical data, the gross collection of grain crops will be by 5 tons from a hectare less than in the previous year in most regions of the country due to the climate conditions. Therefore, the year of 2017 will become a historic year when Russian farmers sold record 45 million tons of grain abroad. Nevertheless, many agricultural producers consider this season as the worst one from the point of economy. The main reason is decreasing grain prices. The fall of world prices, ruble strengthening, and grain overproduction played its role here. However, despite some anxious expectations the future of the main industry in the South of Russia looks very optimistic.

\section{References:}

Agroinvestor. 2018. Agro-news portal. Available at: https://www.agroinvestor.ru/analytics/news

Blokhina, V.G. 2016. The analysis of changeable investment conditions on the macrolevel. Issues of accounting, analysis, audit and statistics under market conditions: studies Issue 19, Rostov-on-Don. RSUE, 272.

Blokhina, V.G., Naydenko, A.V. 2018. Issues of economic analysis at agricultural enterprises. Statistics in the modern world: methods, models, tools. Proceedings of VI International scientific-practical conference RSUE, Rostov-on-Don, 256-261.

Demyanenko, E.Yu. 2010. Specifics of accounting agricultural export. Current issues in accounting, analysis and audit in agroindustry, Proceedings of the round table: the collection of scientific works, Rostov-on-Don, 52-57.

Demyanenko, E.Yu., Smertina, E.N. 2016. Financial tools in agricultural production and perspectives of the development in the market economy. Universities: Science and Enlightenment, 21, 224.

GKS. 2017. The Federal service of state statistics "Rostov region in figures". Short statistical compendium, Rostov-on-Don.

Kommersant. 2017. Golubev's crop. Available online: https://www.kommersant.ru/doc/3390192

Radchenko, Yu.V. 2018. The analytical justification of management strategy of business solvency. Accounting and statistics, 3 .

RUSAGROTRANS, 2016. Grain market review. Available at: http://www.rusagrotrans.ru/analitika/rynok-zerna/obzor-rynka-zerna-po-sostoyaniyuna-17-08-2016/

Smertina, E.N. 2011. The problems of food and economic safety in agricultural production in Rostov region. Proceedings of scientific-practical conference "Interaction of the society and the state in the period of Russian modernization", Yaroslavl, Moscow, Kanzler. 